\title{
Reformasi Birokrasi Lintas Generasi Pada Sektor Transportasi Publik (Studi kasus persepsi generasi Y dan Z)
}

\section{Cross Generation Bureaucratic Reform In Public Transportation (Case Study: Generation $Y$ and $Z$ Perception)}

\author{
Teguh Budi Santoso, Okki C. Ambarwati, Rino A. Nugroho, Didik G. Suharto \\ Universitas Sebelas Maret \\ tegubudis@ outlook.com,okkiambarwati@student.uns.ac.id,rino.nugroho@staff.uns.ac.id, \\ didikgsuharto@yahoo.com
}

\begin{abstract}
Abstrak
Pelayanan publik di bidang transportasi saat ini telah menuntut dilakukan reformasi birokrasi dengan menggunakan teknologi didalamnya. YLKI menyebutkan bahwa karena buruknya layanan transportasi publik menyebabkan berkembanglah transportasi online di masyarakat. Mayoritas pengguna transportasi online adalah masyarakat generasi Y dan Z. Artikel ini bertujuan melihat faktor-faktor penggunaan transportasi online dari generasi tersebut dengan Technology Acceptance Model (TAM) sebagai pertimbangan dalam reformasi di bidang transportasi. Penelitian ini menggunakan pendekatan kuantitatif dan analisis PLS SEM. Hasil penelitian menunjukkan ada perbedaan faktor antara generasi $\mathrm{Y}$ dan $\mathrm{Z}$ dalam menggunakan transportasi online. Hasil dan implikasinya di bahas lebih lanjut dalam artikel ini.
\end{abstract}

\section{Kata kunci: transportasi online, TAM, generasi}

\begin{abstract}
Nowadays, public services in transportation sector are required to carry out bureaucratic reform by using technology in it. YLKI pointed out that due to poor public transportation services, led to development of online transportation in society. Most users of online transportation are people from generation $\mathrm{Y}$ and $\mathrm{Z}$. The aim of this article is to look some factors that affect the use of online transport from those generations using Technology Acceptance Model (TAM) as a consideration in transportation reform. This research use quantitative approach and SEM PLS analysis. The results show that there is a difference factor between generation $\mathrm{Y}$ and $\mathrm{Z}$ in using online transport. The results and their implication are discussed further in this article..
\end{abstract}

Keywords: online transportation, TAM, generation

\section{A. Pendahuluan}

Birokrasi merupakan salah satu jenis organisasi yang dikemukakan oleh Max

Weber. Birokrasi menurut Weber merupakan organisasi ideal dengan ciri tugas rutin dan spesialisasi, aturan formal, tugas dikelompokkan ke departemen fungsional, wewenang terpusat, rentang kendali sempit, dan pengambilan keputusan yang sesuai dengan rantai komando (Robbins \& Judge, 2008). Birokrasi juga dapat diartikan sebagai 
suatu sistem yang mengatur jalannya pemerintahan dan pembangunan. Dari kedua pengertian tersebut dapat disimpulkan bahwa birokrasi merupakan jenis organisasi yang memiliki karakteristik organisasi ideal khusus untuk mengatur jalannya pemerintahan dan pembangunan. Karakteristik organisasi ideal dalam birokrasi pada pelaksanaanya memiliki banyak hambatan diantaranya red tape, $\mathrm{KKN}$, mempertahankan status quo, patronase, dll. Untuk mengantisipasi hal tersebut pemerintah perlu memberlakukan reformasi birokrasi pada tubuh birokrasi Indonesia.

Selain untuk mengantisipasi hambatan yang ada, manfaat lain dari reformasi birokrasi adalah terciptanya pelayanan publik yang berkualitas. Reformasi birokrasi saat ini mengarah pada paradigma New Public Service (NPS). Hal utama yang menjadi ciri khas dari paradigma ini adalah adanya koalisi antara organisasi publik, swasta, dan non-profit untuk mencapai tujuan kebijakan serta terciptanya pelayanan publik yang lebih baik (Denhardt \& Denhardt, 2007).

Salah satu cara melakukan reformasi birokrasi adalah dengan melakukan inovasi yang memanfaatkan kemajuan teknologi. Hal ini untuk membantu menghilangkan patologi yang ada dalam tubuh birokrasi serta meningkatkan efektivitas dan efisiensi birokrasi. Prinsip ini biasa disebut dengan prinsip $e$ governance. E-governance merupakan penggunaan teknologi dan informasi pada proses governance dimana dalam proses tersebut terlibat berbagai aktor yaitu pemerintah, privat, dan organisasi nonprofit (Nurhadryani, 2009). Melalui penerapan e-governance dalam reformasi admnistrasi publik akan menunjang perwujudan konsep New Public Service pada birokrasi di Indonesia.

Berdasarkan hasil survey yang dikeluarkan oleh The Worldwide Governance Indicators (2017), ditemukan bahwa kinerja governansi Indonesia masih berada di tingkatan menengah ke bawah. Dari 6 dimensi yang diukur, yaitu Voice and Accountability, Political Stability and Absence of Violence/Terrorism, Government Effectiveness, Regulatory Quality, Rule of Law, dan Control of Corruption, angka tertinggi yang diraih oleh Indonesia adalah 0,14 (dari rentang nilai -2,5 sampai 2,5) pada dimensi Voice and Accountability dimana jika dilihat berdasarkan peringkat, angka tersebut hanya ada di kisaran rata-rata. Hal tersebut merupakan salah satu alasan yang memperkuat mengapa reformasi birokrasi perlu dilakukan di Indonesia.

Bidang transportasi khususnya transportasi publik merupakan salah satu sektor publik yang perlu dilakukan reformasi di dalamnya. Hal tersebut karena transportasi merupakan sarana yang sangat penting dalam menunjang keberhasilan pembangunan (Biro Komunikasi dan Informasi Publik Kementrian Perhubungan, 2017). Transportasi umum darat merupakan moda transportasi yang paling sering digunakan. Tetapi kualitas pelayanan yang diberikan oleh pihak penyedia layanan transportasi ini belum cukup baik, sehingga menyebabkan banyak masyarakat yang belum mau menggunakannya. 
Di negara berkembang sendiri, kendala dalam transportasi umum darat yang sering ditemui antara lain; kendaraan yang digunakan sering melebihi kapasitas (sebagai akibat dari usaha pengemudi untuk meningkatkan pendapatannya), pengemudi yang tidak sabar, ketidaktepatan waktu, dan tingkat keamanan yang rendah menyebabkan maraknya pencurian (Iles, 2005). Sebagai dampak dari buruknya layanan tersebut menurut Tim Peneliti Yayasan Layanan Konsumen Indonesia (2017) mengakibatkan munculnya transportasi online di masyarakat.

Dari survey cross-media link diketahui bahwa pengguna transportasi online di Indonesia mencapai $48 \%$ dari populasi pengguna internet di Indonesia. Penggunaan teknologi dalam transportasi publik yang berwujud transportasi online merupakan dampak dari penyesuaian ruang dan waktu oleh adanya teknologi. Ada empat manfaat yang dihasilkan dari penyesuaian tersebut yaitu; Time-space convergence, menjelaskan bahwa ketika teknologi digunakan dalam transportasi akan terjadi penurunan tingkat ruang/waktu dalam proses transportasi (Janelle,1968); Time-space compression, percepetan peristiwa dalam kehidupan sehari-hari yang dihasilkan karena penggunaan teknologi khususnya teknologi transportasi oleh manusia (Harvey,2001); Human extensibility, individu menggunakan teknologi untuk menunjukkan kehadirannya tanpa harus berada di tempat dimana ia harus hadir; Trackability, penggunaan teknologi di bidang transportasi akan memudahkan masyarakat untuk mengetahui kondisi transportasi public. yang akan mereka gunakan (Janelle, D. G. and Gillespie, A, 2004).

Berdasarkan survey yang dilakukan oleh Pusat Kajian Komunikasi Universitas Indonesia (2017), mayoritas pengguna transportasi online di Indonesia berusia lebih dari 20 tahun tetapi kurang dari 30 tahun (56\%), lalu diikuti pada peringkat kedua adalah penduduk yang berusia lebih dari 30 tahun tetapi kurang dari 40 tahun $(28 \%)$. Jika ditinjau dari perbedaan generasi, ada dua generasi yang dominan dari kedua kelompok tersebut, yaitu generasi $\mathrm{Y}$ dan generasi $\mathrm{Z}$. Benscik, Csikos \& Juhaz (2016) menjelaskan bahwa generasi Y adalah generasi yang berisi orang-orang kelahiran antara tahun 19801995 sedangkan generasi $\mathrm{Z}$ adalah generasi yang berisi kelahiran antara tahun 1995-2010. Selain sebagai konsumen terbesar dalam penggunaan transportasi online, berdasarkan proyeksi Badan Perencanaan Pembangunan Nasional (2013) tahun 2018, jumlah penduduk Indonesia akan mencapai 265 juta jiwa, dimana penyumbang populasi terbesar adalah dari kedua generasi tersebut. Generasi Y menyumbang 31,56\% terhadap populasi sedangkan generasi $\mathrm{Z}$ menyumbangkan $26,13 \%$.

Menghadapi tantangan tersebut maka reformasi birokasi di bidang ini sangatlah diperlukan. Penggunaan teknologi dalam rangka reformasi layanan publik saat ini juga sudah menjadi keharusan, karena kedua generasi yang menjadi mayoritas penduduk Indonesia saat ini adalah generasi yang melek teknologi. Namun sayangnya tidak semua penggunaan teknologi oleh pemerintah berhasil. Heeks (2003) dalam risetnya menyebutkan bahwa 
di negara berkembang adopsi teknologi di bidang ini $35 \%$ gagal total, $50 \%$ gagal dan $15 \%$ berhasil. Dengan melihat minat terhadap transportasi, penelitian ini mencoba melihat adopsi penerimaan teknologi di bidang transportasi yang berupa transportasi berbasis aplikasi online dengan menggunakan dasar teori Technology Adoption Model (TAM) dari perspektif generasi $\mathrm{Y}$ dan $\mathrm{Z}$. Dari hal tersebut akan didapat variable yang menunjukkan preferensi public saat ini sehingga dapat menjadi masukan dalam reformasi birokrasi di bidang transportasi. TAM merupakan teori yang banyak digunakan oleh para peneliti untuk melihat adopsi sebuah teknologi dari penggunanya (Bhatttacharjee, 2001). Variabel dari TAM yang digunakan dalam penelitian ini adalah Perceived of usesfulness (PU), Perceived Eassy of Use (PEOU) terhadap Intention of Use (IU). Selain itu, penelitian ini juga menambahkan variable Perceived of Risk untuk melihat penerimaan teknologi.

Secara lebih rinci, proses penerimaan teknologi dapat dijelaskan melalui model yang diperkenalkan oleh Davis pada tahun 1986. Menurut teori ini, ada dua hal yang mendasari intensitas perilaku seseorang dalam penggunaan teknologi yaitu perceived usefulness dan perceived ease of use. Perceived usefulness terkait dengan tingkat kepercayaan seseorang bahwa sistem yang ia gunakan akan meningkatkan performa kerjanya sedangkan perceived ease of use terkait dengan tingkat kemudahan yang seseorang rasakan dalam menggunakan sistem yang ada (Davis, 1989). Perceived of use dan perceived usefulness akan mempengaruhi sikap seseorang terhadap sistem dan selanjutnya terhadap intensitas perilaku seseorang dalam menggunakan sistem tersebut (Intention of use).

Berbagai macam modifikasi telah dilakukan dalam model yang diperkenalkan Davis, salah satunya adalah masuknya variabel perceived of risk sebagai variabel yang mempengaruhi intention of use (Nugroho,2015). Perceived of risk adalah persepsi konsumen mengenai ketidakpastian dan konsekuensi negatif yang mungkin diterima atas pembelian suatu produk atau jasa (Olgethrope, 1994). Perceived risk memiliki hubungan negatif dengan Intention of use masyarakat, artinya semakin tinggi tingkat perceived risk maka akan semakin rendah penggunaan sistem oleh masyarakat dan sebaliknya ( Lai, P. C., \& A, Z. A., 2015). Sehingga hipotesis dalam penelitian ini dapat disusun sebagai berikut:

H1: Terdapat pengaruh signifikant antara Perceived of usesfulness (PU) terhadap Intention of Use (IU) transportasi Online.

$\mathrm{H} 2$ : Terdapat pengaruh signifikant antara Perceived Eassy of Use (PEOU)terhadap Intention of Use (IU) transportasi Online.

H3: Terdapat pengaruh signifikant antara Perceived of Risk (PR) terhadap Intention of Use (IU) transportasi Online

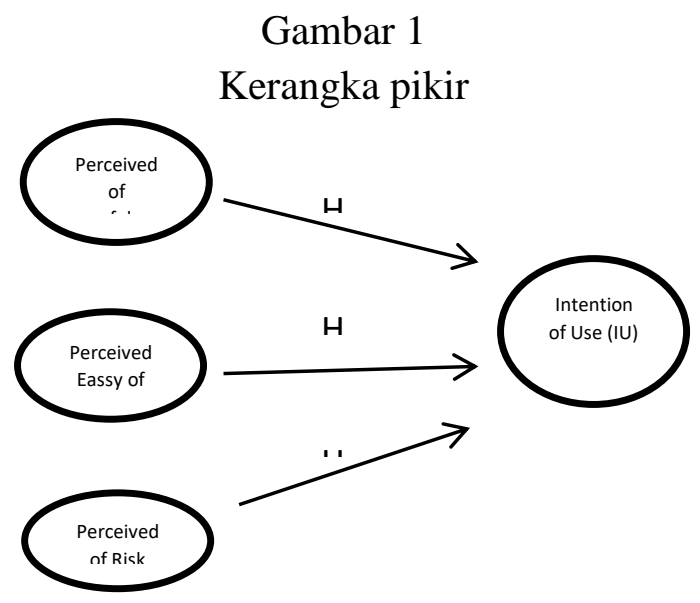




\section{B.Metode Penelitian}

Penelitian ini menggunakan pendekatan kuantitatif dengan studi kasus melihat persepsi dua generasi terhadap pelayanan publik berbasis online yang saat ini banyak digunakan oleh penggunanya (transportasi online). Benscik, A., Csikos, G., \& Juhaz, T. (2016) mengklasifikasikan generasi menjadi beberapa jenis, yaitu: Generasi Veteran (1925-1946), Generasi Baby Boomer (1946-1960), Generasi X (19601980), Generasi Y (1980-1995), Generasi Z (1995-2010) dan Generasi Alfa (2010+). Dalam penelitian ini, generasi yang dilihat adalah generasi $\mathrm{Y}$ dan $\mathrm{Z}$, dengan jumlah 36 responden di masing-masing generasi.

Sampling dalam penelitian ini diambil secara non-probablity sampling. Penelitian ini menggunakan variable Perceived of usesfulness (PU), Perceived Eassy of Use (PEOU), Intention of Use (IU) dan Perceived of Risk (PR) untuk melihat penerimaan teknologi di transporasi online. Analisis data dalam penelitian ini menggunakan PLS SEM dengan software SMART PLS 3.0 dalam pengolahannya. Tahap measurement model dilakukan untuk mengetahui realibilitas dan validitas serta coefficient determinan $\left(\mathrm{R}^{2}\right)$. Kemudian tahap structuring model untuk mengetahui predictive relevance $\left(\mathrm{Q}^{2}\right)$. Kualitas model ditentukan bila $\mathrm{R}^{2}$ dan $\mathrm{Q}^{2}$ memiliki nilai yang sama-sama bagus. Untuk menguji hipotesisnya melihat dari P-Valuenya.

\section{C.Pembahasan}

\section{Profil Responden}

Data profil dari responden dalam penelitian ini adalah sebagai berikut :

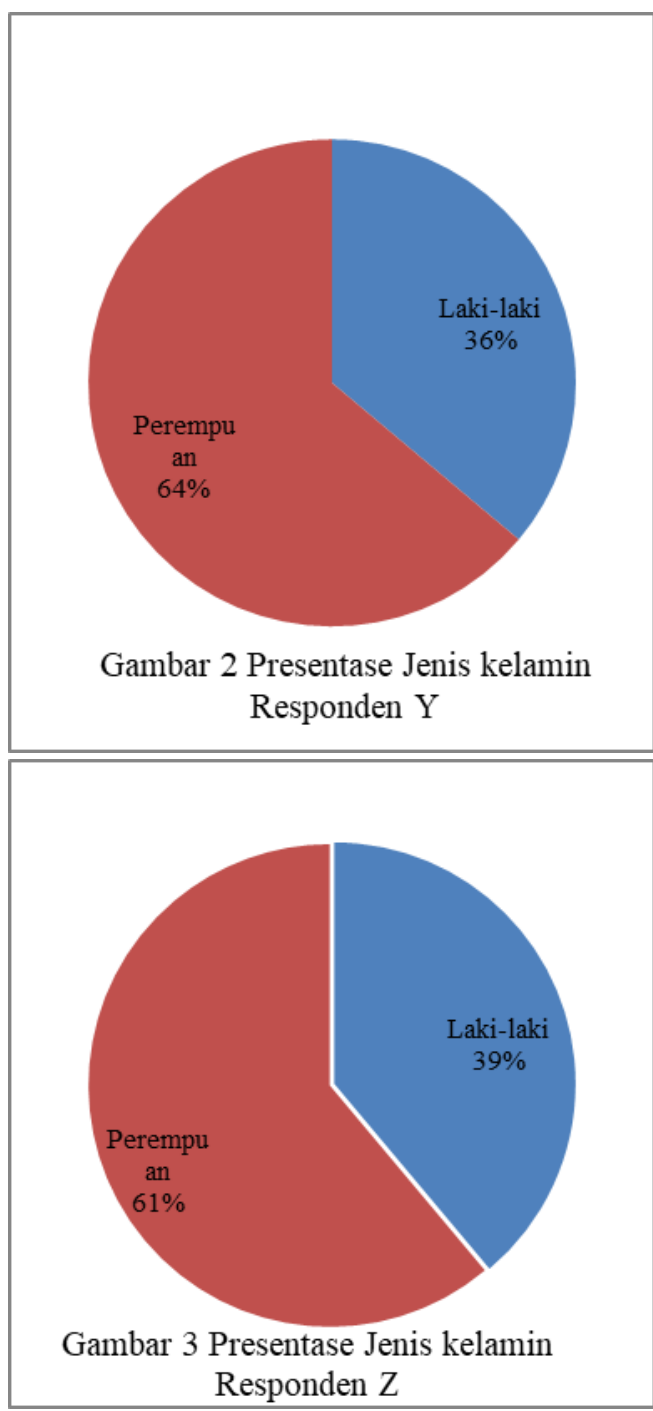

Dari gambar 2 dapat dilihat bahwa responden untuk generasi $\mathrm{Y}$ laki-laki berjumlah $36 \%$, sedangkan perempuan ada $64 \%$. Kemudian responden generasi $\mathrm{Z}$ dari gambar 3, responden perempuan sebanyak $61 \%$, sedangkan laki-laki 39\%. Melihat profil dari dua generasi dapat dipaparkan bahwa pengguna layanan aplikasi online mayoritas adalah perempuan.

\section{Measurement Model}

Tahap pertama yang dilakukan yakni analisis reflektif measurement model. Indikator dari instrument diambil dari riset terkait yang di sesuaikan konteks penelitian yang mengukur masing-masing variabel, kemudian diuji realibitas serta validitasnya. 
Tabel 1

Measurement Model kelompok generasi Y

\begin{tabular}{|c|c|c|c|c|c|}
\hline $\begin{array}{l}\text { Vari } \\
\text { able }\end{array}$ & $\begin{array}{l}\text { Indi- } \\
\text { cators }\end{array}$ & $\begin{array}{l}\text { Loa } \\
\text { dings }\end{array}$ & $\begin{array}{l}\text { Compo } \\
\text { site } \\
\text { reliabl } \\
e\end{array}$ & $A V E$ & $\begin{array}{l}\text { Discrimi } \\
\text { nant } \\
\text { validity }\end{array}$ \\
\hline \multirow[t]{4}{*}{$P U$} & PU1 & 0,626 & \multirow[t]{4}{*}{0,828} & \multirow[t]{4}{*}{0,551} & \multirow[t]{4}{*}{$\mathrm{Ya}$} \\
\hline & PU2 & 0,830 & & & \\
\hline & PU3 & 0,615 & & & \\
\hline & PU4 & 0,864 & & & \\
\hline \multirow{3}{*}{$\begin{array}{l}P E O \\
U\end{array}$} & PEOU1 & 0,941 & \multirow[t]{3}{*}{0,950} & \multirow[t]{3}{*}{0,864} & \multirow[t]{3}{*}{$\mathrm{Ya}$} \\
\hline & PEOU2 & 0,960 & & & \\
\hline & PEOU3 & 0,886 & & & \\
\hline \multirow[t]{3}{*}{$P R$} & PR1* & 0.014 & \multirow[t]{3}{*}{0,806} & \multirow[t]{3}{*}{0,680} & \multirow[t]{3}{*}{$\mathrm{Ya}$} \\
\hline & PR2 & 0,675 & & & \\
\hline & PR3 & 0,947 & & & \\
\hline \multirow[t]{4}{*}{$(I U$} & IU1 & 0,895 & \multirow[t]{4}{*}{0,896} & \multirow[t]{4}{*}{0,685} & \multirow[t]{4}{*}{$\mathrm{Ya}$} \\
\hline & IU2 & 0,854 & & & \\
\hline & IU3 & 0,688 & & & \\
\hline & IU4 & 0,859 & & & \\
\hline
\end{tabular}

Tabel 2

Measurement Model kelompok generasi Z

\begin{tabular}{|c|c|c|c|c|c|}
\hline $\begin{array}{l}\text { varia } \\
\text { ble }\end{array}$ & $\begin{array}{l}\text { Indi- } \\
\text { cators }\end{array}$ & $\begin{array}{l}\text { Loa } \\
\text { dings }\end{array}$ & $\begin{array}{l}\text { Compo } \\
\text { site } \\
\text { reliabl } \\
e\end{array}$ & $A V E$ & $\begin{array}{l}\text { Disc } \\
\text { rimi } \\
\text { nant } \\
\text { valid } \\
\text { ity }\end{array}$ \\
\hline \multirow[t]{4}{*}{$P U$} & PU1 & 0,894 & \multirow[t]{4}{*}{0,931} & \multirow[t]{4}{*}{0,772} & \multirow[t]{4}{*}{$\mathrm{Ya}$} \\
\hline & PU2 & 0,855 & & & \\
\hline & PU3 & 0,881 & & & \\
\hline & PU4 & 0,885 & & & \\
\hline \multirow{3}{*}{$\begin{array}{l}\text { PEO } \\
U\end{array}$} & PEOU1 & 0,846 & \multirow[t]{3}{*}{0,828} & \multirow[t]{3}{*}{0,618} & \multirow[t]{3}{*}{$\mathrm{Ya}$} \\
\hline & PEOU2 & 0,668 & & & \\
\hline & PEOU3 & 0,823 & & & \\
\hline \multirow[t]{3}{*}{$P R$} & PR1* & $-0,734$ & \multirow[t]{3}{*}{0,782} & \multirow[t]{3}{*}{0,643} & \multirow[t]{3}{*}{$\mathrm{Ya}$} \\
\hline & PE2 & 0,622 & & & \\
\hline & PE3 & 0,833 & & & \\
\hline \multirow[t]{4}{*}{$(I U$} & IU1 & 0,820 & \multirow[t]{4}{*}{0,902} & \multirow[t]{4}{*}{0,756} & \multirow[t]{4}{*}{$\mathrm{Ya}$} \\
\hline & 世2* & 0,553 & & & \\
\hline & IU3 & 0,808 & & & \\
\hline & IU4 & 0,905 & & & \\
\hline
\end{tabular}

Reflektive measurement model dalam analisis SEM diukur dengan beberapa langkah, diantaranya dari composite realibility, indicator realibility, average variance extracted (AVE) dan discriminant validity. Untuk mengetahui apakah konstruk tersebut realibel maka harus melihat pada outer loadings. Outer loading yakni seberapa banyak variasi dari item indikator dijelaskan oleh konstruk (Hair et.al 2014). Variasi nilai outer loading antara 0 dan 1 , dimana semakin besar nilainya maka semakin tinggi pula tingkat realibilitasnya. Menurut Hair et al
(2014), nilai dibawah 0,60 menunjukkan bahwa item indikator kekurangan konsistensi realibiltasnya. Jika nilai outer loading kecil, langkah yang bisa diambil adalah dengan menghapus item indikator tersebut. Nilai outer loading diantara 0,400,70 dapat dihapus apabila menaikkan nilai AVE dan composite realibility. Menurut Hair et al (2011), nilai outer loading dibawah 0,40 pasti harus dieliminasi.

Tabel 1 dan 2 menunjukkan bahwa item indikator yang dihapus adalah PR1. Hilangnya item tersebut dapat menaikkan nilai AVE sehingga nilainya lebih dari 0,5. Tabel 1 menunjukkan bahwa konstruk realibel. Setelah dipastikan reliabel, selanjutnya memastikan validitas dengan melihat angka convergent validity (AVE). Hair et.al (2014) mengemukakan standar valid adalah 0,5 maka semakin tinggi angka, konstruk semakin valid. Tabel 1 menunjukkan bahwa discriminat validity dikatakan ya, maka nilai PU, PEOU, PR dan UI terhadap dirinya lebih besar daripada dengan konstruk lainnya.

\section{Structural Model}

Tahap pengujian yang dilakukan berikutnya adalah menguji structural model. Tahap ini dilakukan setelah indikator sebelumnya sudah dinyatakan realibel dan valid. Struktural model pada adalah mencari coeficient determinan $\left(\mathrm{R}^{2}\right)$ dan predictive relevance $\left(\mathrm{Q}^{2}\right)$. 
Tabel 3

Struktural model pada kelompok generasi

Y dan Generasi Z

\begin{tabular}{|l|l|l|}
\hline & $\begin{array}{l}\text { P-Value di } \\
\text { Generasi Y }\end{array}$ & $\begin{array}{l}\text { P-Value } \\
\text { di } \\
\text { Generasi } \\
\text { Z }\end{array}$ \\
\hline PU $\rightarrow$ IU & 0,000 & 0,346 \\
\hline $\begin{array}{l}\text { PEOU } \rightarrow \text { I } \\
\text { U }\end{array}$ & 0,941 & 0,001 \\
\hline PR $\rightarrow$ IU & 0,027 & 0,098 \\
\hline
\end{tabular}

Coeficient determinan $\left(\mathrm{R}^{2}\right)$ menunjukkan kemampuan variabel independen menjelaskan variabel dependen dalam predictive accuracy. Menurut Hair et al (2004) untuk penelitian behaviour, angka dengan nilai 0,2 sudah diangap tinggi. Predictive relevance $\left(\mathrm{Q}^{2}\right)$ digunakan dalam blindfolding yaitu teknik memprediksi akurasi dari point data setiap indikator dalam reflektive measurement model. Nilai $\mathrm{Q}^{2}$ harus lebih besar dari nol agar model memiliki predictive relevance. Di generasi $\mathrm{Y}$, nilai $\mathrm{R}^{2}$ dan $\mathrm{Q}^{2}$ masingmasing adalah 0,542 dan 0,300 . Sedangkan generasi $\mathrm{Z}$ nilai $\mathrm{R}^{2}$ dan $\mathrm{Q}^{2}$ masing-masing adalah 0,600 dan 0,381 . Baik $\mathrm{R}^{2}$ dan $\mathrm{Q}^{2}$ dari masing-masing generasi memiliki nilai yang bagus dan dalam kategori moderate.

\section{Uji Hipotesis}

Untuk menguji hipotesis dengan melihat pengaruh siginifikan antara variabel independen dengan vaiabel dependen dari uji p-values. Level of confindence yang digunakan sebesar 0,05. Berikut tabel hasil uji p-values:
Tabel 4

Hasil Uji P-Values kelompok generasi Y dan Z

\begin{tabular}{|l|l|l|l|l|}
\hline & \multicolumn{2}{|l|}{ Generasi Y } & \multicolumn{2}{|l|}{ Generasi Z } \\
\hline $\begin{array}{l}\text { Variab } \\
\text { le }\end{array}$ & $\mathbf{R}^{\mathbf{2}}$ & $\mathbf{Q}^{\mathbf{2}}$ & $\mathbf{R}^{\mathbf{2}}$ & $\mathbf{Q}^{\mathbf{2}}$ \\
\hline $\mathbf{I U}$ & $\begin{array}{l}0,54 \\
2\end{array}$ & $\begin{array}{l}0,30 \\
0\end{array}$ & $\begin{array}{l}0,60 \\
0\end{array}$ & $\begin{array}{l}0,38 \\
1\end{array}$ \\
\hline
\end{tabular}

H1 : Ada pengaruh signifikan antara PU terhadap UI

Hasil dari tabel 4 menunjukkan bahwa nilai p-values di generasi Y adalah 0,000. Ini berarti hasil signifikan karena pvalues kurang dari 0,05. Maka, hipotesis 1 di generasi Y diterima. Sedangkan nilai pvalues values di generasi $\mathrm{z}$ adalah 0,346. Ini berarti hasil tidak signifikan karena pvalues lebih dari 0,05. Maka, hipotesis 1 untuk generasi $\mathrm{Z}$ ditolak.

\section{H2: Ada pengaruh signifikan PEOU} terhadap UI.

Tabel 4 menunjukkan bahwa nilai p-values di generasi $Y$ adalah 0,941. Ini berarti hasil tidak signifikan karena p-values lebih dari 0,05. Maka, hipotesis 2 untuk generasi Y ditolak. Sedangkan nilai p-values di generasi $\mathrm{Z}$ 0,001. Ini berarti hasil signifikan karena $p$-values kurang dari 0,05. Maka, hipotesis 2 untuk generasi $\mathrm{Z}$ diterima.

\section{H3: Ada pengaruh signifikaan PR terhadap UI}

Tabel 4 menunjukkan bahwa nilai p-values di generasi Y 0,027. Ini berarti hasil signifikan karena $p$-values kurang dari 0,05. Maka, hipotesis 3 kelompok generasi Y diterima. Sedangkannilai pvalues di generasi $\mathrm{Y}$ adalah 0,098. Ini berarti hasil tidak signifikan karena $p$ - 
values lebih dari 0,05. Maka, hipotesis 1 untuk kelompok generasi $\mathrm{Z}$ ditolak.

\section{Reformasi Birokrasi Sektor Transportasi Publik.}

Tujuan dari penelitian ini adalah menjelaskan perbedaan perspektif generasi $\mathrm{Y}$ dan $\mathrm{Z}$ dalam menggunakan moda transportasi online. Dari penelitian ini terlihat bahwa terdapat perbedaan faktor yang menentukan kedua generasi tersebut dalam menggunakan transportasi online. Hal ini menjadi temuan menarik ternyata variabel yang mempengaruhi antar generasi dalam menggunakan sistem itu berbeda, dan saling bertolak belakang meskipun kedua generasi tersebut merupakan generasi yang sama-sama lahir di era perkembangan teknologi.

Pada generasi $\mathrm{Y}$, faktor yang menjadi penentu penggunaan transportasi online oleh generasi tersebut adalah perceived of use dan perceived of risk. Dengan kata lain, orang-orang pada generasi ini ketika menggunakan transportasi online, mereka akan mempertimbangkan tingkat kegunaan dan risiko dari moda transportasi tersebut. Sehingga pemerintah nantinya dalam menyelenggarakan transportasi publik berbasis online dalam sosialisasi digenerasi Y perlu ditekankan pada aspek kegunaan dan tingkat resiko yang memungkinkan terjadi.

Sedangkan untuk generasi Z, pertimbangan utama mereka ketika memilih transportasi online adalah perceived ease of use, yaitu tingkat kemudahan dalam menggunakan moda transportasi tersebut. Maka sosialisasi yang perlu ditekankan oleh pemerintah di generasi ini adalah aspek mudahnya sistem tersebut.

Ketiga faktor tersebut dapat dijadikan pertimbangan pemerintah dalam melakukan reformasi di bidang transportasi. Selain itu reformasi yang dilakukan adalah dengan cara merubah jenis transportasi, yaitu dari transportasi konvensional menjadi transportasi berbasis teknologi yaitu transportasi online. Perubahan jenis tersebut penting dilakukan karena sebagian besar masyarakat Indonesia terdiri dari generasi $\mathrm{Y}$ dan generasi $\mathrm{Z}$, kedua generasi tersebut merupakan generasi yang akrab dengan teknologi.

Generasi Y merupakan gelombang pertama generasi digital, generasi ini memiliki kualifikasi yang tinggi dalam teknologi informasi (Benscik, A., Csikos, G., \& Juhaz, T. , 2016) sedangkan generasi $\mathrm{Z}$ adalah generasi yang lahir di tengahtengah kemajuan era digital, generasi ini biasa disebut dengan iGeneration atau Digital Natives (Tari in Benscik, A., G, H.-C. \& T, J ,2016). Mengetahui hal tersebut, sudah seharusnya pemerintah melakukan perubahan berbasis teknologi di bidang transportasi, yaitu transportasi online sebagai jawaban atas tantangan yang ada.

\section{D.Kesimpulan}

Berdasarkan hasil penelitian ini, dapat dilihat bahwa telah ada perbedaan perspektif antara generasi $\mathrm{Y}$ dan $\mathrm{Z}$ dalam memakai transportasi online. Hal ini berimplikasi pada perbedaan strategi sosialisasi dari pemerintah. Dapat disimpulkan reformasi birokrasi Indonesia dalam menghadapi tantangan generasi 
(generasi Y dan Z), khususnya di bidang transportasi harus memperhatikan tiga faktor yaitu perceived of usefulness, perceived of risk, dan perceived ease of used. Ketiga hal tersebut dapat ditemukan pada adopsi teknologi di sistem transportasi online yang ada di Indonesia. Ketika akan melakukan reformasi sistem transportasi publik menjadi transportasi publik berbasis teknologi, maka sudah seharusnya pemerintah memperhatikan ketiga hal tersebut.

Penggunaan transportasi online dirasa penggunanya dapat menyelesaikan beberapa permasalahan yang terdapat pada transportasi publik konvensional. Berdasarkan survey YLKI, terdapat empat alasan mengapa masyarakat memilih menggunakan transportasi online saat ini, yakni: murah, cepat, nyaman, dan aman. Keempat hal tersebut merupakan jawaban atas streotipe buruk yang muncul pada transportasi publik di negara berkembang. Ketika permasalahan esensial dalam transportasi publik terselesaikan maka minat masyarakat menggunakan transportasi publik bisa meningkat. Sehingga perlu diepertimbangkan penerapan transportasi publik berbasis online.

Selain itu, penggunaan transportasi publik online juga dapat berdampak pada terwujudnya smart governance dan good governance. Penggunaan teknologi akan membuat pemerintahan yang lebih baik dan progresif, memperkuat institusi pemerintahan, serta akan membantu proses integrasi antar sektor masyarakat. Implikasi penelitian ini bagi pemerintah, dapat digunakan sebagai acuan untuk melakukan reformasi di bidang transportasi public. Untuk penelitian selanjutnya jika system transportasi publik online tersebut sudah diterapkan, penelitian ini dapat dilakukan sebagai bahan evaluasi terhadap sistem yang sudah ada. Batasan dari penelitian ini adalah terbatasnya sampling sehingga konsekuensinya pada generalisasi.

\section{Daftar Pustaka}

Badan Perencanaan Pembangunan Nasional, 2013. Proyeksi Penduduk Indonesia 2010-2035. [Online]

Available at: https://www.bappenas.go.id/files/5413/ 9148/4109/Proyeksi_Penduduk_Indone sia_2010-2035.pdf

[Accessed 23 Juni 2018].

Benscik, A., G, H.-C. \& T, J., 2016. Y and $\mathrm{Z}$ Generations at Workplaces. Journal Of Competitiveness, 8(3), pp. 90-106.

Bhattacherjee, A. 2001. Understanding information systems continuance: An expectation-confirmation model. MIS Quarterly: Management Information Systems, 25, 351-370.

Biro Komunikasi dan Informasi Publik Kementrian Perhubungan, 2017. Badan Penelitian Dan Pengembangan. [Online] Available at: http://www.dephub.go.id/post/read/tran sportasi-sebagai-pendukung-sasaranpembangunan-nasional [Accessed 20 Juni 2018].

Davis, F. D. 1989. Perceived Usefulness, Perceived Ease of Use, and User Acceptance of Information Technology. MIS Quarterly, 13, 319-340.

Denhardt, J. V. \& Denhardt, R. B., 2007. The new public service : serving, not steering. Expanded ed. Armonk, NY: M.E. Sharpe. 
Hair JR, J. F., Hult, G. T. M., Ringle, C. \& Sarstedt, M. 2014. A primer on partial least squares structural equation modeling $\quad(P L S$-SEM), Sage Publications.

Hair, J. F., Ringle, C. M., \& Sarstedt, M. 2011. PLS-SEM: Indeed a Silver Bullet. Journal of Marketing Theory and Practice, 19(2), 139-151.

Harvey, D., 2001. Spaces of Capital: Towards a Critical Geography. New York: Routledge.

Heeks, R., 2003. Most e-Government for Development Project Fails: How Can Risks be Reduced?, Manchester: Institute for Development Policy and Manajement.

Iles, R., 2005. Problems and Characteristics Of Public Transport in Developing Countries. In: Public Transport In Developing Countries. s.l.:Emerald Group Publishing Limited, pp. 5-37.

Janelle, D. G. \& Gillespie, A., 2004. Space - time Constructs for Linking Information and Space - Time Constructs for Linking Information and Communication Technologies with Issues in Sustainable Transportation. Transport Reviews, 24(6), pp. 665-677. Janelle, D. G., 1968. Central place development in a time-space framework. Professional Geographer, 20(1), pp. 5-10.

Lai, P. C. \& Zainal, A. A., 2015. Perceived Risk As An Extension To TAM Model: Consumers' Intention To Use A Single Platform E-Payment. Australian Journal of Basic and Applied Sciences, 9(2), pp. 323-331.

Nugroho, R. A., 2015. Electronic Government Adoption in Developing Countries: The Case of the Indonesian
Electronic Procurement System (pp. 1192). Australia: The University of Queensland.

Nurhadryani, Y., 2009. Memahami Konsep E-Governance Serta Hubungannya Dengan E-Government Dan EDemokrasi. Yogyakarta, Seminar Nasional Informatika (SEMNASIF).

Olgethorpe, J. E. \& Miller , M., 1994. Determinant Of Perceived Health and Safety Risk of Selected Hazardous Product and Activities. Journal of Consumer Research, pp. 326-246.

Pusat Kajian Komunikasi Universitas Indonesia , 2017. Hasil Riset Manfaat Sosial Aplikasi On-Demand : Studi Kasus Gojek-Indonesia. [Online]

Available at: http://puskakom.ui.ac.id/publikasi/hasil -riset-manfaat-sosial-aplikasi-ondemand-studi-kasus-gojekindonesia.html [Accessed 23 Juni 2018].

Robbins, S. P. \& Judge, T. A., 2008. Perilaku Organisasi Edisi. 12 ed. Jakarta: Salemba Empat.

World Bank, 2017. The Worldwide Governance Indicators. [Online]

Available at: http://info.worldbank.org/governance/w gi/\#home

[Accessed 22 Juni 2018].

YLKI, 2017. Warta Konsumen: Transportasi Online; Kawan atau Lawan?. [Online]

Available at: https://ylki.or.id/2017/07/wartakonsumen-transportasi-online-kawanatau-lawan/ [Accessed 18 Juni 2018]. 